\title{
Diet of the exotic Rainbow Trout in the critical habitat of the threatened Hooded Grebe
}

\author{
J.L. Lancelotti( ${ }^{(1), \star}$, L.M. Bandieri Bandieri ${ }^{(1)}$, M.A. Pascual ${ }^{(1),(2)}$ \\ Received May 28, 2015 \\ Revised August 27, 2015 \\ Accepted August 31, 2015
}

\section{ABSTRACT}

Key-words: Patagonia, aquaculture, exotic species, species interactions, dietary overlap
The lakes of the basaltic plateaus of Patagonia represent the only reproductive habitat for the critically endangered Hooded Grebe (Podiceps gallardoi). More than 50 of these naturally fishless lakes have been stocked with the exotic Rainbow Trout (Oncorhynchus mykiss). While the available information suggests that the diet composition of trout and Hooded Grebes could overlap, to date no formal studies of the diet of Rainbow Trout in these aquatic environments have been published. We characterized the diet of trout in one of the primary reproductive areas of the Hooded Grebe based on the analysis of the gut contents of 177 individuals, from 9 lakes. Amphipods were clearly the most dominant group of prey, quantified as frequency of occurrence and proportion by weight. The condition factor of trout and the abundance of amphipods in the stomach contents showed a functional relationship, suggesting that the wellness of trout depends on the availability of this prey. Amphipods also represent a primary prey for the Hooded Grebe, suggesting a strong dietary overlap with the trout. The presence of trout may generate processes of competition that could affect the survival of the Hooded Grebe. This interaction may be particularly relevant in large vegetated lakes, where the Hooded Grebe reproduces.

\section{RÉSUMÉ}

Régime alimentaire de la truite arc-en-ciel introduite dans l'habitat essentiel du grèbe mitré menacé

Mots-clés:
Patagonie,
aquaculture,
espèces
exotiques,
interactions
entre espèces,

Les lacs des plateaux basaltiques de Patagonie représentent le seul habitat de reproduction pour le grèbe mitré en danger critique (Podiceps gallardoi). Plus de 50 de ces lacs naturellement sans poissons ont été empoissonnés avec la truite arcen-ciel (Oncorhynchus mykiss). Bien que les informations disponibles suggèrent que la composition des régimes alimentaires de la truite et du grèbe mitré pourraient se chevaucher, à ce jour, aucune étude formelle de l'alimentation de la truite arc-en-ciel dans ces milieux aquatiques n'a été publiée. Nous avons caractérisé le régime alimentaire de la truite dans l'une des zones de reproduction principales du grèbe mitré basé sur l'analyse du contenu stomacal de 177 truites, provenant 
chevauchement de régime alimentaire de 9 lacs. Les amphipodes étaient clairement le groupe le plus dominant de proies quantifiées aussi bien par la fréquence d'occurrence que la proportion en poids. Le facteur de condition de la truite et l'abondance des amphipodes dans le contenu de l'estomac ont montré une relation fonctionnelle, ce qui suggère que le bien-être de la truite dépend de la disponibilité de cette proie. Les amphipodes représentent également une proie principale pour le grèbe mitré, suggérant un chevauchement important de l'alimentation avec celle de la truite. La présence de la truite peut générer des processus de concurrence qui pourraient affecter la survie du grèbe mitré. Cette interaction peut être particulièrement importante dans les grands lacs avec végétation, où le grèbe mitré se reproduit.

\section{INTRODUCTION}

Most of the fresh water in the southern Patagonian steppe is located in a system of basaltic plateaus (mesetas) that hold the largest lakes of this region, as well as thousands of smaller shallow lakes. These aquatic environments represent the primary habitat for numerous species of waterbirds, including several endemisms and threatened species (Di Giacomo, 2005; Lancelotti et al., 2009a), and are the only reproductive area for the threatened Hooded Grebe (Podiceps gallardoi), a diving waterbird considered to be one of the most endangered species in Argentina (Roesler et al., 2012; Birdlife International, 2015). More than 50 of these naturally fishless lakes have been stocked with Rainbow Trout (Oncorhynchus mykiss), generating an extensive aquaculture system, and promoting the economic development of this remote region. These introductions also generate concerns about the potential impact on the receiving communities (Roesler et al., 2011, 2012). For instance, the introduction of Rainbow Trout into the Lake Strobel meseta - that historically has represented the core reproductive habitat for the Hooded Grebe (Imberti, 2005) - has been proposed as one of the primary drivers of the species decline (estimated to be more than $80 \%$ during the last 30 years; Roesler et al., 2012).

Concerns about the potential effects of trout introductions on Hooded Grebe populations are supported by an extensive literature recording alterations derived from the introduction of exotic fishes in aquatic systems worldwide. These alterations include changes in the composition and abundance of species, nutrient availability and nutrient cycles, the primary productivity and trophic relationships, and the behavior and spatial distribution of prey (Carpenter \& Kitchell, 1996; Scheffer, 1998; Donald et al., 2001; Knapp \& Matthews, 2001; Schindler \& Parker, 2001; Eby et al., 2006, Reynolds, 2011). These effects are more drastic in lakes devoid of native fish (Mallory et al., 1994; Donald et al., 2001; Vredenburg, 2004), as is the case of the lakes of the basaltic plateaus of Patagonia. In the Patagonian steppe the introduction of exotic fishes into lakes has been responsible for local extinctions of cladoceran species, the reduction of size in zooplankton and the homogenization of communities (Modenutti \& Balseiro, 1994; Reissig et al., 2006). The translocation of native fish and the introduction of Rainbow Trout into the shallow lake Laguna Blanca $\left(70^{\circ} 22^{\prime} \mathrm{W}, 39^{\circ} 02^{\prime} \mathrm{S}\right)$ led to the local extinction of amphibians, and the loss of habitat for waterbirds (Ortubay et al., 2006) .

Available information suggests that the diet composition of trout and Hooded Grebes - both visual predators - could overlap. The collection of potential prey for both species is restricted to a small number of species of crustaceans (amphipods, copepods and cladocera) and insect larvae (Fjeldsa, 1986; Beltran et al., 1992). Knowledge about the diet of the Hooded Grebe is poor and limited to a few direct observations of feeding behavior. The literature (see Fjeldsa, 1986) and in situ observations suggest that the Hooded Grebe predates mostly on the few large preys of these lakes, mostly snails and amphipods, and also aquatic insects and their larvae. All of these organisms are potential prey for Rainbow Trout, a typical omnivorous species easily adaptable to local conditions of food availability (Quinn, 2005). However, to date no formal studies of the diet of Rainbow Trout in these aquatic environments have been published. Meanwhile, the number of lakes stocked with trout increases from year to year. 
Therefore, the information of the diet composition of this exotic predator is essential to evaluate the potential dietary overlap between the two species and for proposing hypotheses about the effects resulting from trout introduction in this aquatic system. We analyzed the gut contents of 177 individuals of Rainbow Trout from 9 lakes of the Lake Strobel meseta to characterize their diet. Lakes analyzed included the whole range of lake sizes (from 0.13 to $100 \mathrm{~km}^{2}$ ), and limnological characteristics (e.g. macrophyte abundance) of the stocked lakes, as well as two primary reproductive environments of the Hooded Grebe.

\section{METHODS}

\section{> STUDY AREA}

The Lake Strobel meseta $\left(71^{\circ} 22^{\prime} \mathrm{W}, 48^{\circ} 26^{\prime} \mathrm{S}, 2500 \mathrm{~km}^{2}\right.$, Fig. 1), one of the largest basaltic mesetas in Patagonia, is the focus of most of the aquaculture activity. This meseta holds over one thousand lakes, from small temporary ponds to lakes larger than $100 \mathrm{~km}^{2}$ (Lancelotti et al., 2009b). The lakes are natural depressions situated on a basaltic bed of Tertiary and Quaternary origin (Pereyra et al., 2002), which collect water from snow and melting ice. Based on limnological characteristics these lakes have been classified into four categories (Lancelotti et al., 2009b). Those with high conductivity $\left(>2000 \mu \mathrm{S} \cdot \mathrm{cm}^{-1}\right.$ ) and characteristically turbid water (Secchi $<0.5 \mathrm{~m}$ ) represent a distinct lake type (turbid lakes), which includes lakes of variable size (9-27 ha) and generally low depth $(<3 \mathrm{~m})$. The remaining lakes all have clear water and, depending on size and bathymetry, differ in their macrophyte cover and were classified into three different types. Small vegetated lakes (SV) ( $<9$ ha and $<2 \mathrm{~m}$ deep) are fully vegetated, while the other two groups comprise larger lakes ( $>7$ ha and 3-16 m deep), which are either heavily vegetated (large vegetated, LV, 15-30\% emergent macrophyte cover), or sparsely vegetated (large unvegetated, LU, $<15 \%$ emergent macrophyte cover).

There are few invertebrate species in these lakes (Lancelotti, 2009). Pelagic organisms are largely represented by crustaceans, with a prevalence of calanoid copepods of the genus Boeckella, and Cladocera (represented mostly by Daphnia spp.). Ostracods have relatively low abundance. Eight species of calanoid copepods have been identified in the Lake Strobel meseta, but no more than three different species are numerically dominant (Lancelotti, 2009). Benthic organisms are primarily represented by oligochaetes, chironomidae larvae, hirudineas and gastropods (this last group is not present in every lake). Hyalella represents the only genus of amphipods recorded in the Lake Strobel meseta (Lancelotti, 2009). Aquatic insects are dominated by chironomidae larvae and coleoptera. Neither amphibians nor native fish inhabit the lakes of this basaltic meseta system.

Lakes present a rich waterbird community, with over 20 species, including the near-threatened Magellanic plover (Pluvianellus socialis) and Chilean flamingo (Phoenicopterus chilensis) (Lancelotti et al., 2009a, 2009b). From October to March the Hooded grebe congregates in the basaltic mesetas to reproduce. Throughout the ample gradient of lake characteristics, Hooded grebes strongly prefer lakes with a combination of emerged macrophytes (dominated by the Myriophillum elatinoides) surrounded by open water areas (Fjeldsa, 1986; Lancelotti et al., 2010). The Myriophillum generate carpets over the water surface, where Hooded Grebes build their nests using the macrophytes as building material. During the reproductive period the parents reside in the colony, feeding the chicks with prey captured in open water areas (Fjeldsa, 1986).

More than 40 fishless lakes of the Lake Strobel meseta have been stocked with Rainbow Trout, generating an extensive aquaculture system, which consists of stocking fry (approximately 6000 individuals per $\left.\mathrm{km}^{2}\right)$ in medium-sized lakes $\left(0.05-0.71 \mathrm{~km}^{2}\right.$, mean $\left.0.19 \mathrm{~km}^{2}\right)$. Harvest takes place two to three years after the stocking, when fish reach commercial size (fork length $>20 \mathrm{~cm}$ ), and then lakes are stocked again, starting a new cycle of production. In general, farmers prefer to stock large unvegetated lakes, where trout harvest with gillnets is the easiest. However, in several of the large vegetated lakes trout have also been stocked at the onset of the aquaculture activity. On the other hand, all small vegetated and turbid lakes 


\section{Table I}

Summary of lake characteristics and trout samples. Lakes were classified into types based on their limnological characteristics (Lancelotti, 2009b); LU and LV correspond to large unvegetated and large vegetated lakes, respectively. Lake area (Area) was estimated using satellite images (Landsat 7). Depth corresponds to the maximum depth recorded in each lake. Stocked refers to the year (spring) of the first fish stock. Season is the date of fish capture. $N$ is the sampling size. $K$ is the mean value of the condition factor. NA indicates non-available data.

\begin{tabular}{|l|c|c|c|c|c|c|c|c|}
\hline Lake & Type & Area & Depth & Stocked & Season & $N$ & Trout length & $K$ \\
\hline Chanchos & LU & 0.6 & NA & 1996 & Feb-05 & 18 & $34.0-43.6$ & 1.33 \\
Campamento & LU & 0.43 & 16 & 1996 & Dic-04 & 10 & $33.0-38.0$ & 1.16 \\
Potrero & LU & 0.79 & 15 & 2001 & Dic-05 & 37 & $14.5-45.0$ & 1.6 \\
La Pala & LU & 0.47 & NA & 2003 & Mar-05 & 31 & $19.0-35.0$ & 1.64 \\
La Española & LU & 0.13 & NA & 2003 & Mar-05 & 12 & $21.9-28.1$ & 1.62 \\
Rodriguez & LU & 0.24 & 22 & 2003 & Dic-06 & 14 & $28.4-36.3$ & 0.89 \\
Herradura & LV & 0.17 & 9 & 2000 & Dic-06 & 38 & $18.8-70.0$ & 1.24 \\
Islote & NA & 7 & $>40$ & 2003 & Dic-10 & 8 & $60.0-72.0$ & 1.5 \\
Strobel & NA & 100 & $>40$ & 1995 & Dic-04 & 9 & $46.0-62.5$ & 1.7 \\
\hline
\end{tabular}

remain fishless (Lancelotti et al., 2010). Because of habitat restrictions (e.g. lack of permanent streams and adequate spawning beds) trout do not reproduce in most of the shallow lakes of the Lake Strobel meseta. Therefore, trout populations are completely regulated by stocking and fishing.

\section{$>$ SAMPLING}

We analyzed the stomach contents of 177 trout captured in nine lakes (Table I). Lakes analyzed were selected taking into account the wide range of limnological characteristics of the stocked lakes. This array of lakes includes eight lakes used for aquaculture and one large lake used for fly fishing (Strobel). Aquaculture lakes were represented by six large unvegetated lakes, and two large vegetated lakes (Islote and Herradura); the last two represent primary reproductive habitats for the Hooded Grebe (Lancelotti et al., 2009b). Finally, the Lake Strobel is the largest lake of this meseta $\left(100 \mathrm{~km}^{2}\right)$, which sustains sport fishery activity. The trout population of the Strobel lake is self-sustainable through natural reproduction, and was originated through the stocking of the Barrancoso river (in 1997), the only tributary of this lake.

Trout were captured with gillnets, covering a wide range of trout sizes, from 14.5 to $72 \mathrm{~cm}$ (fork length, Table I), during spring and summer, matching with the reproductive period of the Hooded Grebe. Individual trout were measured (fork length, FL), weighed, and their stomachs were conserved in formalin solution (10\%). Stomach contents were analyzed with a stereoscopic microscope. Preys were grouped into five general categories: amphipods, copepods, cladocera, ostracoda and insects. For each stomach we counted all individuals of each previously defined group. Additionally, for samples with abundant prey we pooled individuals of the same group to estimate the mean individual weight. Then, for each stomach we estimated the biomass of each group of organisms as the product of the mean individual weight and their frequency.

\section{> DATA ANALYSIS}

The proportion of weight in the gut contents for each defined group of prey was calculated as:

$$
\widehat{W}_{l}=\frac{W_{i}}{\sum_{i=1}^{n} W_{i}}
$$


where $W_{i}$ is the weight of the prey $i$ and $n$ is the number of prey types in the stomach. Then for each trout population (lakes) we calculated the mean proportion by weight as follows:

$$
W_{i}=\frac{1}{p} \sum_{j=1}^{p} \frac{W_{i j}}{\sum_{i=1}^{n} W_{i j}}
$$

where $p$ is the number of fish with food in the stomach, and $j$ is the number of fish.

We estimated the confidence interval for the mean proportion by weight for each prey group and each lake by means of bootstrap analysis (Manly, 1991). For each trout population we generated a simulated population, of the original population size, taking a random sample with replacement of individuals. Then, based on the simulated population we estimated and recorded $W$ for each prey item. This process was replicated 5000 times. Based on these 5000 estimations we obtained the confidence interval $(\alpha=0.05)$ of this index for each type of prey and for each trout population.

In a second analysis we evaluated the relationship between the trout condition and diet. We calculated Fulton's condition factor ( $k$; Pope \& Kruse, 2007) as an estimator of the wellness of trout:

$$
K_{i}=\frac{W_{i}}{F L_{i}^{3}} \times 100
$$

where $K$ is the condition factor, $W$ is the fish weight, $F L$ is the fork length and $i$ is the ith individual. This index is widely used for fish. For trout, values of $\mathrm{K}$ lower than 1 indicate poor condition (lower values of weight than expected for the fish length, assuming an isometric growth model) and values higher than 1 indicate good condition (higher values of weight than expected for the fish length). Finally, we used a linear model to evaluate the relationship between the frequency of amphipods (in weight), which represent the primary prey of trout (see results), and the condition factor. For this analysis we pooled the individual data of all trout populations (lakes) into a single cluster.

\section{RESULTS}

Amphipods were present in every single trout stomach collected from the collection of lakes, with the exception of Lake Chanchos (presence in $83 \%$ of the individuals; Table II). Cladocera, copepods and insects were also important prey in terms of frequency of occurrence, but these groups showed high variations in the occurrence index, from $0 \%$ to $75 \%$ for cladocera, $0 \%$ to $83 \%$ for copepods, and $0 \%$ to $90 \%$ for aquatic insects. Amphipods and cladocerans were the most numerous preys (Table II), with high variation in numbers, especially for cladocera. Besides, in several lakes trout preyed on a higher number of daphnids than amphipods (e.g. Chanchos, Potrero and La Pala).

The dominance of amphipods in the stomach contents was most manifest in terms of proportion by weight (Figure 2). In eight of the nine analyzed lakes amphipods presented mean values of proportion by weight higher than $60 \%$, and in five of these lakes the values were higher than $90 \%$. The highest values of this index were observed in the two largest lakes, Strobel (99.5\%) and Islote (99.6\%). Trout of two medium-sized lakes, Potrero and La Pala, also showed a high proportion of amphipods in the stomach ( $94.2 \%$ and $94.7 \%$, respectively). Trout from Lake Rodriguez had a low proportion of amphipods (35.5\%) in their stomachs, not significantly different than the proportion of aquatic insects (64\%).

The condition factor of trout and the abundance of amphipods in the stomach contents showed a functional relationship (Figure 3). Trout with higher frequency of amphipods in the stomach contents showed higher values of the condition factor. The lowest mean value of the condition factor was obtained in the Lake Rodriguez (Table I), the lake with the lowest proportion of amphipods in the diet. 


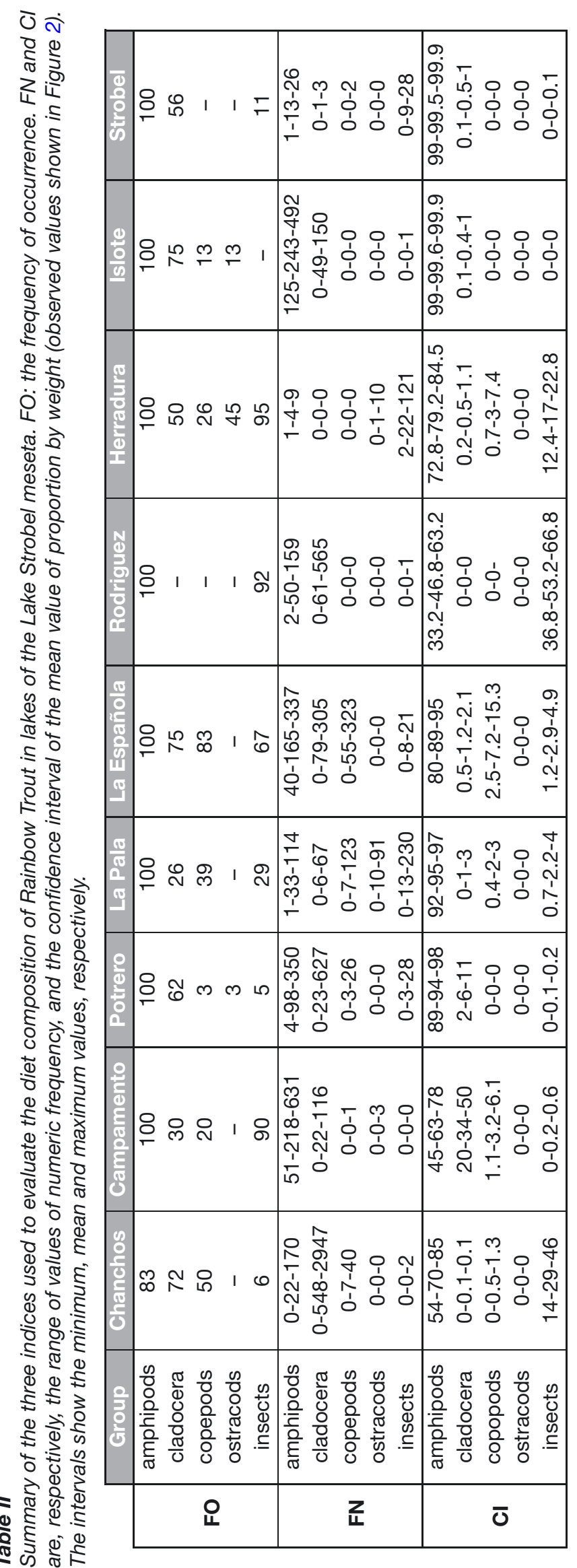




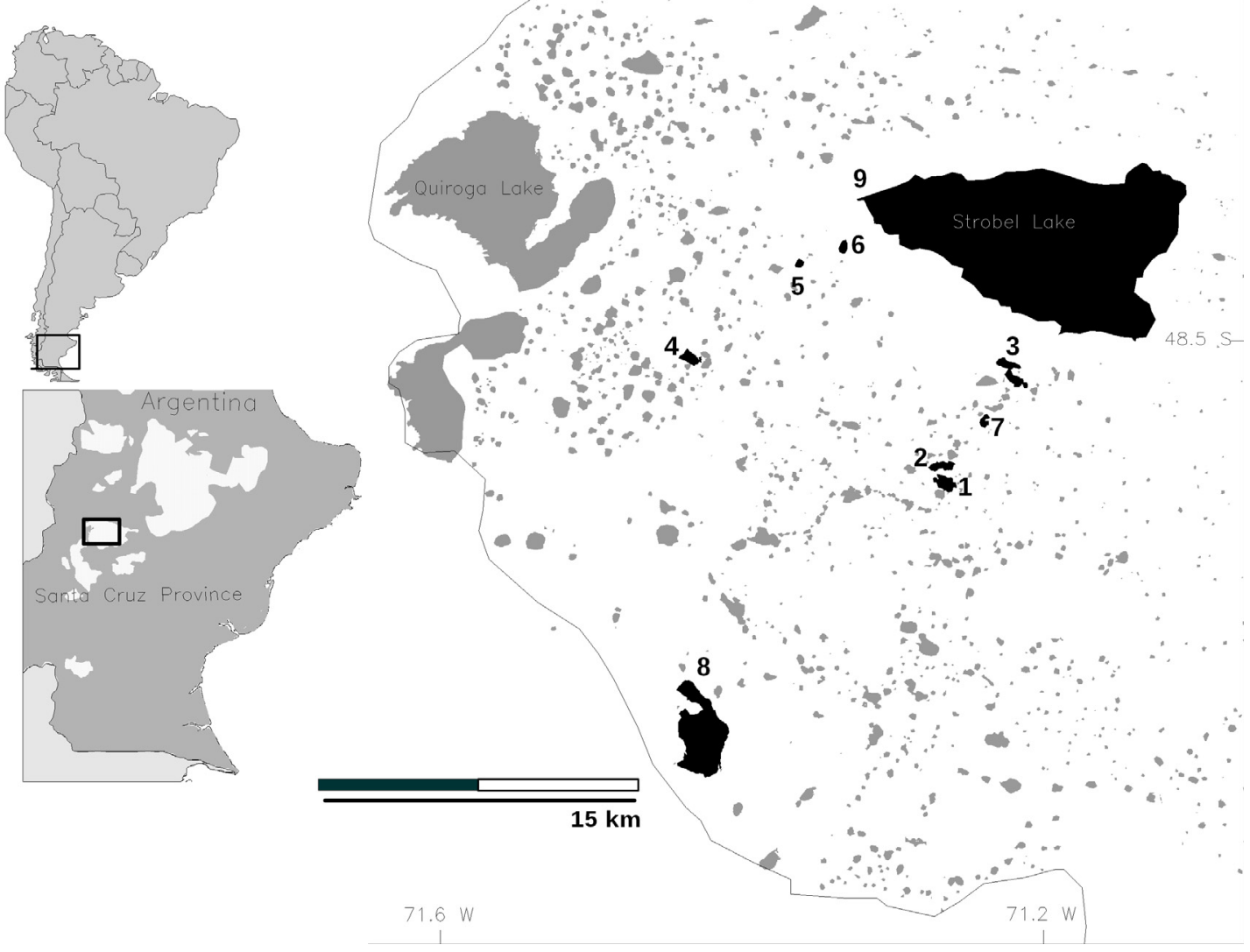

\section{Figure 1}

Map of lakes of the Lake Strobel meseta obtained from a satellite image (Landsat7). The satellite image was processed to mask land and highlight water bodies (in gray, surveyed lakes in black and numbered). Inset shows Santa Cruz Province (Argentina), basaltic mesetas in gray and Lake Strobel meseta (black rectangle). Numbers 1 to 9 correspond, respectively, to the surveyed lakes Chanchos, Campamento, Potrero, La Pala, La Española, Rodríguez, Herradura, Islote and Strobel.

\section{DISCUSSION}

In the lakes of the basaltic mesetas of Patagonia, copepods and cladocera strongly dominate the communities numerically, and are substantially more abundant than amphipods (Lancelotti, 2009). However, amphipods are among the largest prey in these lakes, where adults and larvae of aquatic insects are restricted to littoral rocks and macrophytes, suggesting that trout selectively predate on amphipods. Additionally, the results suggest that the wellness of trout could depend on the availability of this prey. However, this relationship could respond to other environmental variables not analyzed here, and therefore to evaluate this hypothesis it is necessary to conduct specific experiments; for example, analyzing changes in diet and growth during the fishery history in individual lakes.

Amphipods and snails represent the bulk of the Hooded Grebe diet (Fjeldsa, 1986). However, only a few lakes of the Lake Strobel meseta have snails. Besides, snails were absent in all lakes analyzed in this study, as well as in an array of fishless lakes with similar characteristics, including vegetated and unvegetated lakes, of the Lake Strobel meseta (Lancelotti, 2009). Therefore, amphipods could represent one of the primary prey for Hooded Grebes, especially in unvegetated lakes, where these organisms represent the only abundant large prey. Large unvegetated lakes were frequently used by non-breeding flocks of Hooded Grebes in periods previous to trout introductions (Fjeldsa, 1986), whereas the presence of this species was 

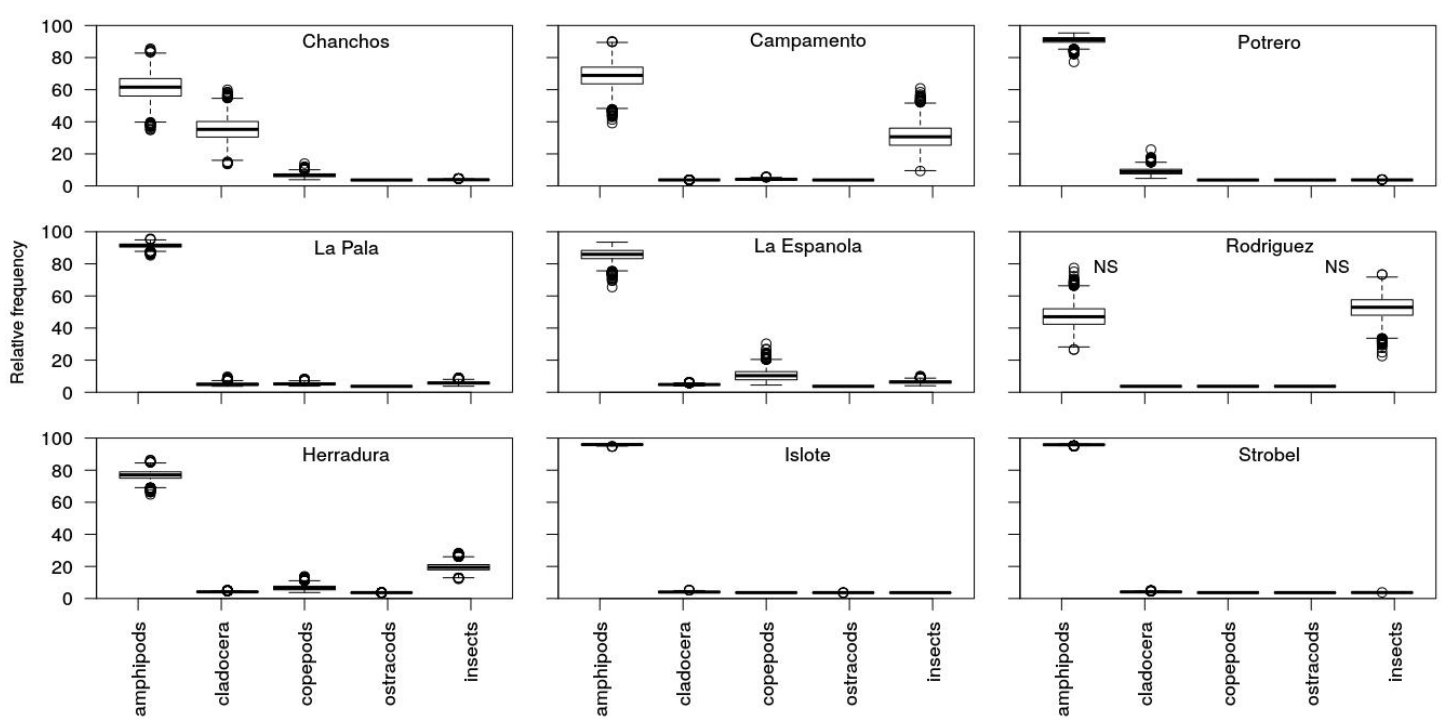

Figure 2

Proportion by weight of prey of trout from nine lakes in the Lake Strobel meseta. The horizontal line represents the median value. The lower and upper hinges represent, respectively, the $25 \%$ and $75 \%$ percentile. NS labels in the panel corresponding to the Lake Rodriguez indicate no significant differences between amphipods and insects in the gut contents of trout from this lake.

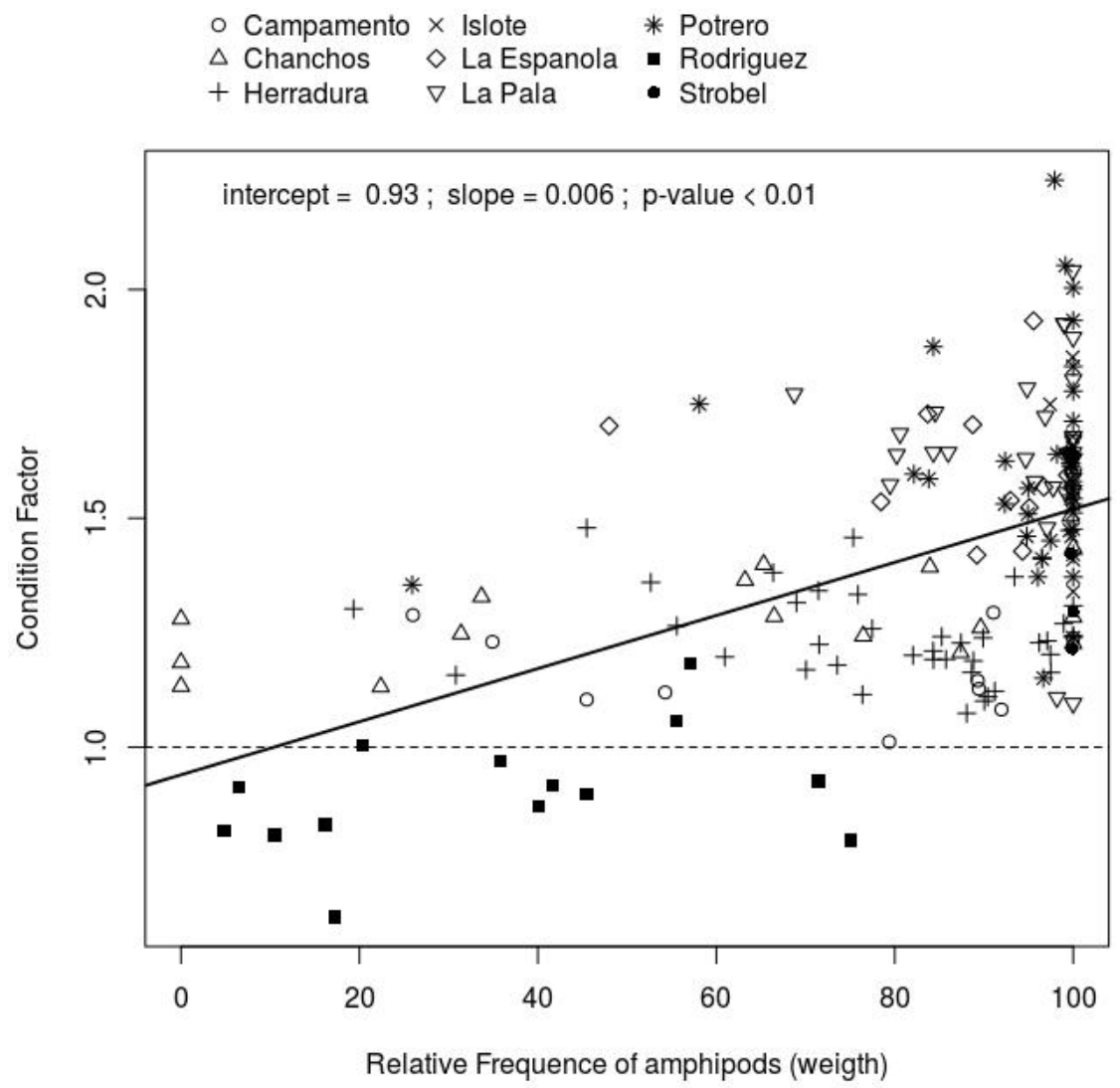

Figure 3

Relationship between the condition factor of trout, and the proportion by weight of amphipods in the stomach contents. For this analysis the samples of trout of all lakes were pooled into a single group. The dashed line indicates the expected value of the condition factor, assuming an isometric model of growth $(k=1)$. 
seldom observed after the trout introduction in these lake types (Lancelotti et al., 2010). This observed change in lake use could respond to a decrease in prey abundance as a direct effect of trout predation.

The interaction between Rainbow Trout and Hooded Grebes may be particularly relevant in large vegetated lakes, where the Hooded Grebe reproduces. Amphipods and large coleopterans of the family Dytiscidae are abundant in the macrophyte areas, which represent the main feeding habitat for Hooded Grebes. Coleopterans also represent a sizable and palatable prey for trout, but this item was seldom observed in their stomach contents, suggesting that the abundance of these organisms in the large vegetated lakes stocked with trout has decreased during the aquaculture period. In this context, the diet composition of trout could be varied during the fishery history, and therefore the actual diet could be responding to a modified environment.

The abundance of large prey represents one of the key factors determining the reproductive success of the Hooded grebe (Fjeldsa, 1986). Predation by grebes can generate strong declines in prey in areas next to the colonies, leading to starvation and eventually the abandoning of chicks (Fjeldsa, 1986). This process could be strongly intensified by trout predation, with its derived effects on the reproductive success of the Hooded Grebe.

To date, no legal restrictions are imposed on aquaculture, and this activity could therefore potentially be extended to most of the permanent lakes of the basaltic mesetas of Patagonia. For instance, partially vegetated lakes are likely to be increasingly used as the preferred nonvegetated lakes are used up, which could increase the spatial overlap between trout and the Hooded Grebe (Lancelotti et al., 2010). Besides, two of the most important reproductive habitats for Hooded Grebes, the Islote lake (included in this study) in the Lake Strobel meseta, and Lake El Sello $\left(71^{\circ} 20^{\prime} \mathrm{W}, 46^{\circ} 55^{\prime} \mathrm{S}\right)$ in the Lake Buenos Aires meseta, have been stocked with trout in recent years.

In 2014 the Patagonia National Park was created, with the protection of the Hooded Grebe and its habitat as a main objective. This National Park contains the most important known reproductive sites of this species. Meanwhile, in areas with aquaculture, more active directives for conservation are required. The authorization for stocking new sites should be based on previous assessment of the value of target lakes as a habitat for Hooded Grebes, reducing the risk of stocking vegetated lakes. These conservation actions should be complemented by the removal of trout from suitable sites for Hooded Grebe reproduction.

The provincial fishery agency (Subsecretaría de Pesca), responsible for regulating and controlling aquaculture activities, is limited economically and logistically, and is unable to supervise this extensive and remote region. Therefore, managers should motivate the collaboration of fish farmers, stimulating the application of appropriate aquaculture practices through financial incentives, and the diversification of the economic activities (i.e. bird watching, ecotourism).

\section{ACKNOWLEDGEMENTS}

We thank the Rodriguez family and the lodge Laguna Verde for allowing us to survey lakes within Estancia Lago Strobel, and Laguna Verde for providing us with logistical support. We are grateful to Martín García Asorey for assistance during field trips. This research was funded by CONICET, Aves Argentinas AOP through the "Macá Tobiano" project, and ANCyT PICT 2013-0794.

\section{REFERENCES}

Beltran J., Bertonatti C., Johnson A., Serret A. and Sutton P., 1992. Actualizaciones sobre la distribución, biología y estado de conservación del Macá tobiano (Podiceps gallardoi). El Hornero, 13, 193-199.

Birdlife International, 2015. Species factsheet: Podiceps gallardoi. Downloaded from http://www.birdlife. org on 18/02/2015. IUCN Red List for birds. 
Carpenter S.R. and Kitchell J.F., 1996. The Trophic Cascade in Lakes. Cambridge University Press, New York, $384 \mathrm{p}$.

Di Giacomo A.S., 2005. Areas importantes para la conservación de las aves en Argentina. Sitios prioritarios para la conservación de la biodiversidad. Aves Argentinas - Asociación Ornitológica del Plata, Buenos Aires, 514.

Donald D.B., Vinebrooke R.D., Anderson R.S., Syrgiannis J. and Graham M.D., 2001. Recovery of zooplankton assemblages in mountain lakes from the effects of introduced sport fish. Can. J. Fish. Aquat. Sci., 58, 1822-1830.

Eby L.A., Roach W.J., Crowder L.B. and Stanford J.A., 2006. Effects of stocking-up freshwater food webs. Trends Ecol. Evol., 21, 576-584.

Fjeldsa J., 1986. Feeding ecology and possible life history tachtics of the Hooded grebe Podiceps gallardoi. Ardea, 74, 40-58.

Imberti S., 2005. Meseta Lago Strobel. In: Di Giacomo A.S. (ed.), Áreas Importantes para la Conservación de las Aves en Argentina. Sitios prioritarios para la conservación de la biodiversidad, Aves Argentinas/Asociación Ornitológica del Plata, Buenos Aires, 415-416.

Knapp R.A. and Matthews K.R., 2001. Resistance and Resilence of alpine lake fauna to fish introductions. Ecol. Monogr., 71, 401-421.

Lancelotti J.L., 2009. Caracterización limnológica de lagunas de la Provincia de Santa Cruz y efectos de la introducción de Trucha Arco iris (Oncorhynchus mykiss) sobre las comunidades receptoras. Doctoral tesis. Universidad Nacional del Comahue, Río Negro, Argentina.

Lancelotti J.L., Pozzi L.M., Márquez F., Yorio P.M. and Pascual M.A., 2009a. Waterbird occurrence and abundance in the Strobel Plateau, Patagonia, Argentina. Hornero, 24, 13-20.

Lancelotti J.L., Pozzi L.M., Yorio P.M., Diéguez M.C. and Pascual M.A., 2009b. Fishless shallow lakes of Southern Patagonia as habitat for waterbirds at the onset of trout aquaculture. Aquat. Conserv. Mar. Freshw. Ecosyst., 19, 497-505.

Lancelotti J.L., Pozzi L.M., Yorio P.M., Diéguez M.C. and Pascual M.A., 2010. Precautionary rules for exotic trout aquaculture in fishless shallow lakes of Patagonia: minimizing impacts on the threatened hooded grebe (Podiceps gallardoi). Aquat. Conserv. Mar. Freshw. Ecosyst., 8, 1-8.

Mallory M.L., Blancher P.J., Weatherhead P.J. and McNicol D.K., 1994. Presence or absence of fish as a cue to macroinvertebrate abundance in boreal wetlands. Hydrobiologia, 279-280, 345-351.

Manly B.F.J., 1991. Randomization and Monte Carlo methods in Biology. Chapman \& Hall, New York, $283 \mathrm{p}$.

Modenutti B.E. and Balseiro E.G., 1994. Zooplankton size spectrum in four lakes of the Patagonian Plateau. Limnologica, 24, 51-56.

Ortubay S., Cussac V.E., Battini M., Barriga J., Aigo J., Alonso M., Macchi P., Reissig M., Yoshioka J. and Fox S.F., 2006. Is the decline of birds and amphibians in a steppe lake of northern Patagonia a consequence of limnological changes following fish introduction? Aquat. Conserv. Mar. Freshw. Ecosyst., 16, 93-105.

Pereyra F.X, Luís F. and Díaz González E.F., 2002. Geomorfología. In: Haller M.J. (ed.), Geología y Recursos Naturales de Santa Cruz. Relatorio del XV Congreso Geológico Argentino. El Calafate, Santa Cruz, Argentina, 348-352.

Pope K.L. and Kruse C.G., 2007. Condition. In: Guy C.S. and Brown M.L. (eds.), Analysis and Interpretation of Freswater Fisheries Data. American Fisheries Society, Bethesda, Maryland, 423471.

Quinn T.P., 2005. The behavior and ecology of Pacific Salmon \& Trout. Press, American Fisheries Society in asociation with University of Washington, Seattle, WA, $380 \mathrm{p}$.

Reissig M., Trochine C., Queimalinos C., Balseiro E. and Modenutti B.E., 2006. Impact of fish introduction on planktonic food webs in lakes of the Patagonian Plateau. Biol. Conserv., 132, 437-447.

Reynolds J.D., 2011. A review of ecological interactions between crayfish and fish, indigenous and introduced. Knowl. Manag. Aquat. Ecosyst., 401, 10.

Roesler I., Casañas H. and Imberti S., 2011. Final countdown for the Hooded Grebe? Neotropical Birding, 9, 3-7. 
Roesler I., Imberti S., Casañas H., Mahler B. and Reboreda J.C., 2012. Hooded Grebe Podiceps gallardoi population decreased by eighty per cent in the last twenty-five years. Bird Conservation International, 22, 371-382.

Scheffer M., 1998. Ecology of shallow lakes. Chapman \& Hall, New York, 357 p.

Schindler D.W. and Parker B.R., 2001. Biological pollutants: alien fiches in mountain lakes. Water Air Soil Pollution: Focus, 2, 379-397.

Vredenburg V.T., 2004. Reversing introduced species effects: Experimental removal of introduced fish leads to rapid recovery of a declining frog. Proc. Biol. Sci., 101, 7646-7650.

Cite this article as: J.L. Lancelotti, L. Bandieri and M.A. Pascual, 2015. Diet of the exotic Rainbow Trout in the critical habitat of the threatened Hooded Grebe. Knowl. Manag. Aquat. Ecosyst., 416, 26. 